\title{
Abstract \\ Effectiveness of autoimplantation in the treatment of multiple cutaneous warts
}

\author{
Kellapatha $\mathrm{IP}^{1 *}$, Wijesinghe $\mathrm{WAMS}^{2}$, Dissanayake $\mathrm{LP}^{2}$, Kumari GMNC ${ }^{3}$, Madarasingha $\mathrm{NP}^{1}$ \\ ${ }^{1}$ Dermatology Unit, Teaching Hospital Anuradhapura, Sri Lanka \\ ${ }^{2}$ MOH Office NPE, Anuradhapura, Sri Lanka \\ ${ }^{3}$ Teaching Hospital Kandy
}

\begin{abstract}
Background

Viral warts are a common presentation to a dermatogical practice. The standard treatment is freezing with liquid Nitrogen which is a physical ablative method. Viral wart auto-implantation is a known method in the treatment of viral warts, but not very popular in day to day practice.

Methods

A randomized controlled trial was carried out at Dermatology unit, Teaching Hospital Anurdhapura to assess the efficacy and safety of auto-implantation when compared to cryotherapy. A total of 120 patients were randomly allocated to the two treatment arms and the response to treatment was assessed monthly for 12 weeks. To achieve the study objective the deductive approach and quantitative analysis were used. Data were analysed using chi square test and, $\mathrm{P}$ value $<0.05$ was taken as significant.

Results

Out of 103 patients who completed the observational period 54 had received cryotherapy and 49 had autoimplantation of warts. At the end of 12 weeks $90.7 \%$ of patients who received cryotherapy and $36.7 \%$ of patients who had auto-implantation had complete response. Based on the higher cure percentage the preposition was accepted that cryotherapy was a better treatment when compared to auto-implantation. Further analysis revealed that the side effects were less in auto-implantation when compared to cryotherapy.

Conclusion

Cryotherapy gives significantly higher rates of complete response in treating viral warts when compared to autoimplantation $(\mathrm{P}<0.05)$. Although inferior to cryotherapy, auto-implantation could be useful in selected cases of viral warts as a treatment option.
\end{abstract}

Key words: Autoimplntation; Cryotherapy; Viral warts

Copyright: (C) 2015 Kellapatha IP et al. This is an open access article distributed under the Creative Commons Attribution License, which permits unrestricted use, distribution, and reproduction in any medium, provided the original work is properly cited.

* Correspondence : indikaip@yahoo.com

Cite this abstract as: Kellapatha IP, Wijesinghe WAMS, Dissanayake LP, Kumari GMNC, Madarasingha NP. Effectiveness of autoimplantation in the treatment of multiple cutaneous warts. Anuradhapura Medical Journal $2015 ; 9$ (2Supp):S20.

DOI: http://dx.doi.org/10.4038/amj.v9i2Supp.7569 


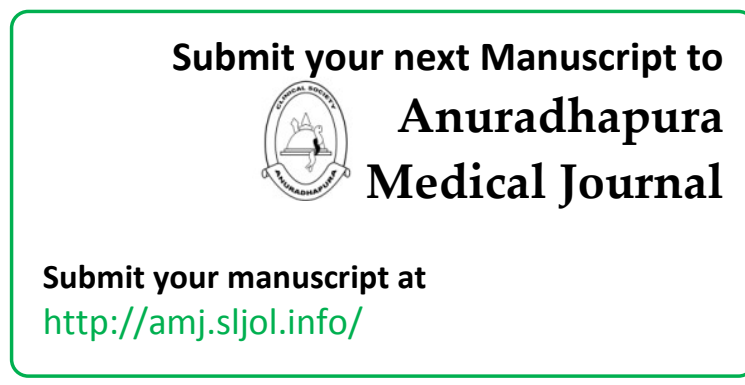

